\title{
BADGES/PINS OF NURSING AND MIDWIFERY SCHOOLS IN SLOVENIA FROM 1925 UNTIL EARLY 1980s
}

\author{
ZNAČKE SESTRINSKIH I PRIMALJSKIH \\ ŠKOLA U SLOVENIJI OD 1925. DO \\ POČETKA 80-ih 20. STOLJEĆA
}

\author{
Janez Fischinger", Duša Fischinger*, Aleš Fischinger ${ }^{* * *}$
}

\begin{abstract}
SuMmARY
Introduction: Many nursing and midwifery schools in many countries around the world awarded or still award graduation badges or pins to their graduates. All graduates from different parts of the former Kingdom of Yugoslavia and later the Republic of Yugoslavia educated in Slovenian healthcare schools received badges from these schools. Some of the graduates later employed in medical institutions across former Yugoslavia wore these badges on their uniforms. The main purpose of this historical research was to establish which Slovenian health care schools awarded the graduation badges and what they looked like. It was also investigated why the badges ceased to be awarded and what motivated Angela Boškin Faculty of Health Care in Jesenice to reintroduce awarding the badges. Methods: Due to a lack of written sources, we conducted 393 face to face and telephonic interviews with former badge recipients across Slovenia. Their existing badges were photographed. On the authors' initiative, a private collection of badges was started. Results: It has been established that in the $20^{\text {th }}$ century all Slovenian secondary health schools awarded badges. The Nursing College, Ljubljana also awarded graduation badges. Five different types of badges in many variants were issued. The first badges were awarded to graduates by Slovenian oldest

* Angela Boškin Faculty of Health Care, Ljubljana, Slovenia.

** Slovenian Scientific Society for the History of Health Culture, Ljubljana, Slovenia.

*** University Medical Centre Ljubljana, Department of Traumatology, Ljubljana, Slovenia.

Correspondence Address: Janez Fischinger, Angela Boškin Faculty of Health Care, Ob železnici 30A, 1000 Ljubljana. E-mail: janez.fischinger@gmail.com.
\end{abstract}


Nursing School, Ljubljana in 1925. The badges ceased to be awarded in the late 1970s and the early 1980 . Some questions about probable reasons for cessation of awarding badges remain unanswered. Less than a fifth of interviewees kept their badges. Graduating nursing badges were reintroduced in Slovenia in 2017 with a new badge which is presented and depicted in this article. The motivation for the reintroduction of graduating badges is also investigated. Discussion and conclusion: Unfortunately, many Slovenian nurses and midwives are not sufficiently aware of the meaning and importance of their badges. Although badges are important for professional image and identity of nurses, badges as a symbol of nursing have become almost completely forgotten. Graduation badges are miniature works of art and are proof of the existence and development of Slovenian healthcare schools. Nursing badges present a part of nursing history as well as being our cultural heritage. The badges deserve to be written and talked about and should be displayed in a planned future Slovenian Health Care Museum.

Keywords: graduation badges/pins, history of nursing and midwifery, nursing and midwifery educational institutions, $20^{\text {th }}$ century, Slovenia

\section{INTRODUCTION}

Old nurses and midwives' badges or pins (hereinafter: nursing badges) are rare in Slovenia. After finding such a badge mixed with numismatic material, the badge evoked the author's interest as an amateur numismatist. A search of the accessible literature was performed, and to the author's knowledge, there were no extensive writings on this topic in Slovenian or even in the worldwide literature.

The tradition of presenting nursing badges originated in the I86os at the Nightingale School of Nursing at St. Thomas Hospital in London. Florence Nightingale having been recently awarded The Red Cross of St. George for her selfless service for the injured and dying in the Crimean War, chose to extend her honour to her most outstanding graduate nurses by presenting each of them with a medal for excellence. ${ }^{1}$ Later on, awarding all graduates with badges became a tradition in Great Britain and the United States of America. The graduation badges are actually medals presented to nurses as honorary awards for their hard study and work and are important evidence of successful competition of medical nursing education. The badges represent symbolic initiation and admission to the nursing profession. The badges were created with the purpose of fostering pride in a noble profession, and for creating a sense of loyalty to the issuing body. ${ }^{2}$ Graduation badge

1 Anon. Nursing Pins in Lorrain School of Nursing, lorrainschoolofnursing.ca, Nursingpins, http://lorrainschoolofnursing.ca/nursing-pins (accessed: 26 January 2020)

2 Callander-Grant, S. (2001), Nurses's badges: archaic symbols or icons of nursing? International History of Nursing Journal, 6(2), 71-74. 
attached to the nursing uniform became an important part of nurses' professional identity, gave her a sense of self-confidence and increased her authority. The graduation badges provided an eloquent proof of the foundation and evolution of nursing schools. In addition, the badges are evidence of the history of nursing. The badges are beautiful miniature works of art, and they are undoubtedly important artefacts of Slovenian cultural heritage.

The first graduation badges, together with graduation certificates, were presented to newly graduated nurses in the United States of America at the end of the rgth century. ${ }^{3}$ Old British nursing badges are presented in a comprehensive review by Meglaughlin. ${ }^{4}$ In the Austro-Hungarian Empire, the State School for Patient Carers awarded badges beginning with the first generation of graduates in I915. Wearing badges on uniforms was obligatory and prescribed by law. ${ }^{5}$ Currently, there is no evidence that anyone from the territory of today's Slovenia, who was trained to become a certified patient carer in Vienna (in today's term - to be a nurse) before the breakup of the Austro-Hungarian Empire, was presented with a graduation badge of the school along with a graduation certificate. Following the Austrian model, the nurses educated in the newly formed Kingdom of Serbs, Croats and Slovenes, were presented with graduation badges to wear on their uniforms. Graduation badges were presented at schools for nurses in Belgrade, Zagreb and Ljubljana. The nurses had to wear graduation badges on their uniforms. The badges that certified nurses received in Croatia before World War II have already been described by Željko Dugac and Katarina Horvat. ${ }^{6}$ The badges which were presented to nurses and midwives in Croatia from I9I4 to I990 were already described in detail by Zlatko Brbora in 2015. Graduation badges awarded to graduates of School for Childcare Nurses are described by Branko Beštak. ${ }^{8}$ Before World War II, several Slovenes were trained at schools for nurses either in Zagreb or in Belgrade, they were presented with badges of the Croatian or Serbian schools respectively. Some Croats studied for nurses or midwives in Slovenia, and they received graduation badges

Brown, T. (1952), Nursing school pins. American Journal of Nursing, 52(10), 1224. https:// doi.org/10.2307/3459842

Meglaughlin, J. (1990). British nursing badges, London: Vade - Mecum Press, 40-41, 47.

Kozon, V. (2006). Pflegephaleristik-Katalog Österreich, Wien: ÖGVP, 8, 11.

Dugac, Ž., Horvat, K. (2013), Službeno, praktično i elegantno: o uniformama sestara pomoćnica-medicinskih sestara od 1920-ih do 1940-ih godina u Hrvatskoj, Acta medico-historica Adriatica, 11(2), 251-74.

7 Brbora, Z. (2015). Službene značke i odore medicinskih sestara, primalja i bolničarki u Hrvatskoj (1914.-1990.), Dubrovnik: Samozaložba, 1-23.

8 Beštak, B. (2006). Značka škole za dječje njegovateljice Medicinskog fakulteta u Zagrebu, Obol XLIV (58), 65-67. 
from Slovenian schools. Dugac cites an example where a nurse, who graduated in Belgrade but worked in Zagreb during the period of the Independent State of Croatia - NDH (194I-I945, World War II), was advised not to wear her graduation badge which she had received in Belgrade. ${ }^{9}$ Several nurses, midwives, and childcare workers from different regions of Yugoslavia who trained in Slovenia and were later employed in Croatia wore their Slovenian graduation badges on their uniforms. ${ }^{10,11}$ The main purpose of this paper in addition to preserving the knowledge about graduation nursing badges was also to establish which Slovenian secondary schools for nurses and midwives and colleges awarded graduation badges and what they looked like.

The additional purposes of the research were to:

- write an article that would be of help in preparing nursing badges exhibitions and serve as a manual for badge collectors

- enable identification of badges worn by nurses on uninscribed photographs

- establish the manner in which badges were awarded

- find out how nurses felt about wearing badges

- examine why nurses agreed or refused to wear badges

- discover what happened to awarded badges

- find out how many nurses still kept their badges

- learn where the nurses kept their badges

- explore why badges ceased to be awarded

- find out what motivated the Angela Boškin Faculty Health Care, Jesenice to reintroduce the tradition of awarding nurses with graduation badges

- test our hypothesis that many Slovenian nurses/midwives do not sufficiently appreciate their graduation badges

The paper is primarily a descriptive piece of graduation badges. Any deeper analysis of the purpose and meaning of badges, as well as the reasons for the ceasing of awarding of badges, are beyond the scope of this paper.

\section{Methods}

A systematic review of domestic and foreign literature was carried out via electronic databases Google search engine, COBIB.SI Biomedicina, dLib.si

Dugac, Ž., Horvat, K. (2013), 251-274.

Ibid.

Brbora, Z. (2015), 1-23. 
Slovenica, digital archives of Slovenian Nursing Review and web sites of Schools for Health Care. Search words in Slovene, English and German were used to search for potential written sources containing whatever data about badges. A review of archives and jubilee catalogues of nine former Slovenian nursing/midwives' secondary schools and Nursing College, Ljubljana was performed. In addition, the search across BSN diplomas, bachelor's and master's theses, and doctoral dissertations related to the history of nursing and newspapers published around the dates of nursing graduation ceremonies was conducted. Data about the evolution of Slovenian nursing/midwifery schools were gathered from two written sources. ${ }^{12,13}$

A written request was sent to the Nurses and Midwives Association of Slovenia and all nine Schools for Health Care, the successors of the former Slovenian schools for nurses/midwives, for any information about the graduation badges. Unfortunately, no additional valuable data were obtained from these written requests. An overview of sources from different countries concerning the awarding of graduation badges was carried out to enable the authors to compare with the tradition of awarding badges in Slovenia. Photographs exhibiting badges on the nurses/midwives' uniforms were collected as well.

A private collection of badges has been started. Badges were bought at auctions, antiquities shops, and flea markets.

Due to the lack of data about the badges in written sources, we decided to interview nurses, midwives, and rarely relatives of deceased nurses/ midwives across Slovenia. In the pilot interviewing, we established that awarding badges ceased from the late I970s to the early I980s. Therefore, we concluded that the interviewing of mostly retired persons would be needed. For this reason, the most significant part of face-to-face interviews was conducted at apartments and nursing homes across Slovenia. The minor part of still working nurses and midwives was interviewed at hospitals. Some interviews were conducted over the phone or by e-mail. A semi-structured series of the predetermined open-ended questions was prepared to carry out the research. The data obtained from interviews were written down. All interviewees were asked if they still kept their badge and a photograph of their badge was taken with their permission.

12 Gradišek, A. (1974), 50 let zdravstvenega strokovnega šolstva na Slovenskem, Zdravstveni obzornik, 8(3), 145-155.

13 Šuštar, B. (1992). Šola za sestre: zdravstveno šolstvo na Slovenskem: razstavni katalog, Ljubljana: Slovenski šolski muzej, 123-4. 
From June 2013 to December 2016, 346-time consuming interviews were carried out. Many elderly interviewees were suffering from different diseases, and many of them were hospitalised or treated in rehabilitation facilities, which significantly prolonged the interviewing period as we had to wait one month or more to conduct many interviews. In an effort to collect whatever missing data about the badges, 47 additional interviews were conducted in the first half of 2018 .

\section{Results}

Only one short article in Slovene describing and depicting two nursing badges was found..$^{14}$ The nursing or midwife badges are only barely mentioned in some Slovene written sources. ${ }^{15,16,17,18}$ The authors were able to find some papers and handbooks concerning badges published in different foreign countries. ${ }^{19}$

In this paper, the graduation badges issued and awarded by nursing and midwives' schools in Ljubljana are described and depicted in the order of the year of their foundation.

The badges awarded by the eight remaining nursing schools across Slovenia have the same shape and design as the badges awarded in Ljubljana and are therefore only mentioned in this paper.

The first school for nurses in Slovenia was founded at the Institute for Social and Hygienic Protection of Children in Ljubljana. The schooling started on January 3, 1924. The monovalent school lasted for one year. It educated both secular and religious nurses. The graduates were presented with an upright oval silver-plated badge, the work of the academic sculptor Alojz Dolinar (I893-I970). ${ }^{20}$ A slightly convex badge features a naked baby

14 Jarnovič, N. (1978), Značke medicinskih sester v Sloveniji, Zdravstveni obzornik, 12(1), 54-5.

15 Pirc, I. (1938). Zdravstvene prilike in delo higijenskih ustanov v Sloveniji 1922-1936.

Zdravje v Sloveniji. II knjiga. Ljubljana: Higijenski zavod v Ljubljani, 437.

16 Šuštar, B. (1992), 123-4.

17 Keršič, I., Magajne, N., Sima, D., Leskovec, I. (2011). Medicinske sestre skozi čas, Ljubljana: Društvo medicinskih sester, babic in zdravstvenih tehnikov Ljubljana, 27.

18 Keršič, I., Klemenc, D. (2016). Pogovor z gospo Marušo Šolar, dobitnico priznanja Zbornice - Zveze za življenjsko delo Angele Boškin, Utrip XXIV (9), 13-15.

19 Cf. footnote 1; Meglaughlin, J. (1990), 40-47; Kozon, V. (2006), 8-11; Dugac, Ž., Horvat, K., (2013), 251-274; Brbora, Z. (2015), 1-23; Meixner Reed, M. (2009), American nursing pins in history and context, [Nurse-enterpreneur-network]. https://sites.google.com/site/nursingpinsandcollectibles (accessed: 26 November 2019); Kaijser, K. (1985). Broscher $i$ svensk sjukvard, Stockholm: Svensk sjuksköterskeföring, 1-60.

20 Jarnovič, N. (1978), 54-5. 


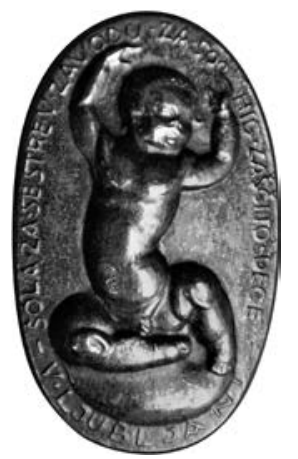

Figure I, left: Ljubljana's School of Nursing graduation badge, awarded from 1925 till I932, height $34,7 \mathrm{~mm}$, width 21,2 $\mathrm{mm}$. Private property.

Slika I., lijevo: diplomska značka Škole za sestre u Ljubljani, dodijeljivana od 1925. do 1932. Visina 34,7 mm, širina 21,2mm. Privatno vlastništvo.

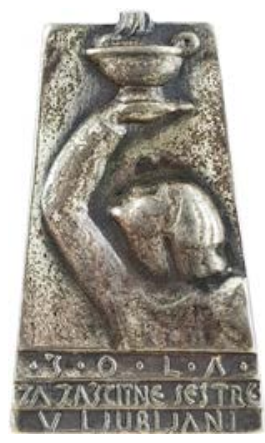

Figure I, right: The Graduation badge of the transformed and renamed School of Nursing, awarded from 1934 till 1947. Height 32,5 mm, width 20,5 $\mathrm{mm}$. Collection Fischinger.

Slika I., desno: diplomska značka preoblikovane in preimenovane, škole dodijelijivana od 1934. do 1947. Visina 32,5mm, širina 20,5mm. Kolekcija

Fischinger.

in relief. Around the edge of the badge, there is an inscription with raised letters of the name of the school: ŠOLA ZA SESTRE V ZAVODUZA SOC. HIG.ZAŠČITO DECE V LJUBLJANI (School for nurses at the Institute for Social and Hygienic Protection of Children). On the rear is a maker's mark from L. Pramer Wien IX (Fig.I, left). In I93I, the school was transformed into a three-year school with polyvalent education and was renamed. Graduates were awarded a newly designed graduation badge. The badge was the work of the academic sculptor France Gorše (I897-I986). ${ }^{21}$ It has the shape of an equilateral trapezoid and is silver-plated. The front face of the badge depicts a relief of a woman in profile with the raised right hand holding a lamp - a symbol of the nurse with the lamp (The Lady with the Lamp) (Fig.I, right). Along the bottom edge is the inscription: ŠOLA ZA ZAŠČITNE SESTRE V LJUBLJANI (The School for Nurses in Ljubljana).

In 1929, the School for Children's Nurses was established at the Institute for Social and Hygienic Protection of Children. The schooling was in the form of 6 months course. In the I930s, schooling was initially extended to one year. ${ }^{22}$ Graduates received graduation certificates and badges. The artist who

21 Ibid.

22 Pirc, I. (1938), 437. 

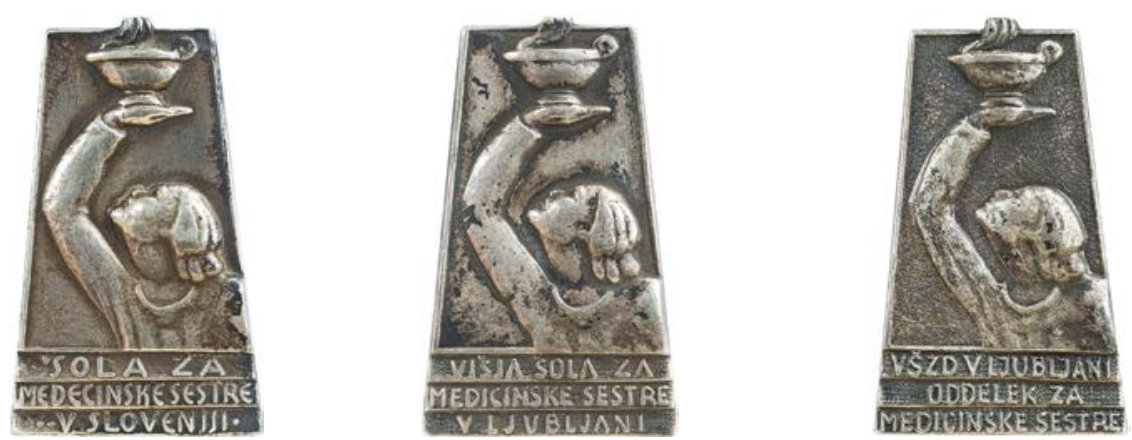

Figure 2, left: Ljubljana's Secondary School of Nursing graduation badge, awarded from the first half of the I950s, height $32,5 \mathrm{~mm}$, width $20,5 \mathrm{~mm}$.

Inscription error: MEDECINSKA instead of MEDICINSKA! Collection Fischinger.

Center: Ljubljana's Nursing College graduation badge, awarded from I954 till I96r. Height 32,5 mm, width 20,5 mm. Collection Fischinger.

Right: Ljubljana's graduation badge of the transformed and renamed College for Health Workers, Department of Nursing, awarded from I962 till 1979, height 32,5 mm, width 20,5 mm. Collection Fischinger.

Slika 2., lijevo: diplomska značka srednje Škole za medicinske sestre u Ljubljani, prva polovica 50-tih godina 20. stojeća. Visina 32,5mm, širina 20,5mm. Greška u natpisu: MEDECINSKA umjesto MEDICINSKA! Kolekcija Fischinger.

U sredini: Značka Višje škole za medicinske sestre u Ljubljani od I954. do I96I. Visina 32,5 mm, širina 20,5mm. Kolekcija Fischinger.

Desno: Značka škole preoblikovane i preimenovane škole u Viša škola za zdravstvene djelatnike - Odjel za medicinske sestre od ig62. do i979. Visina $32,5 \mathrm{~mm}$, širina 20,5mm. Kolekcija Fischinger.

designed the badge is unknown. The badge was manufactured by Josip Štirn, Ljubljana. The badge is circular and silver-plated. The front face of the badge depicts the figure of a woman in profile - the children's nurse - with a baby in her lap. The edge of the badge bears the name of the school: ŠOLA ZA OTROŠKE SESTRE NEGOVALKE (School for Children's Nurses) (Fig.3, left). After World War 2 the school was renamed as ŠOLA ZA OTROŠKE NEGOVALKE (School for Childcare Workers). ${ }^{23}$ The presented graduation badges are identical to the badges given by the School for Children's Nurses, and the new title of the school and no maker's mark are the only differences. (Fig.3, right)

23 Gradišek, A. (1974), 145-155. 

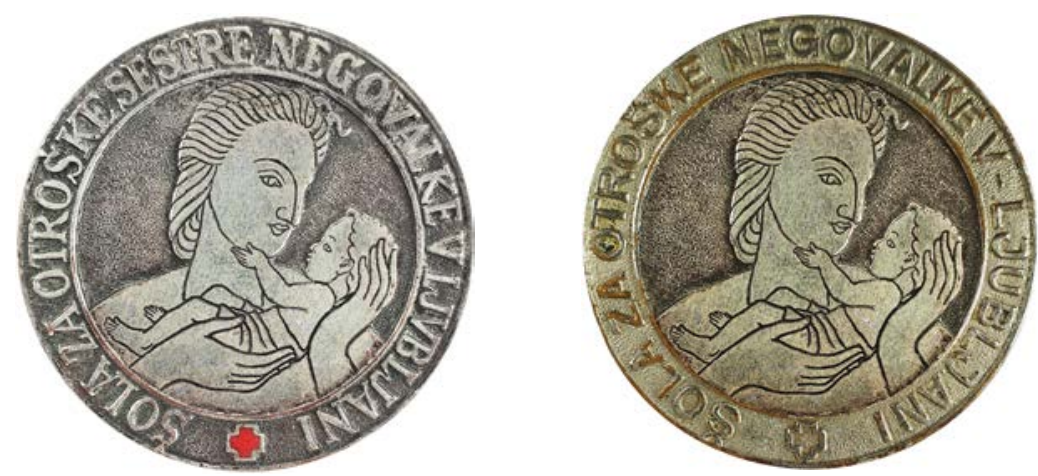

Figure 3, Left: Ljubljana's School of Childcare Workers graduation badge, awarded from I938 till I95. Height $35 \mathrm{~mm}$. Collection Fischinger.

Right: Ljubljana's graduation badges of two-year transformed school, awarded from 1952 till I957, height $35 \mathrm{~mm}$. Collection Fischinger.

Slika 3., Lijevo: diplomska značka Škole za dječje sestre njegovateljice u Ljubljani od 1938. do 1951. Visina $35 \mathrm{~mm}$. Kolekcija Fischinger.

Desno: Diplomska značka preoblikovane i preimenovane škole u Škola za dječje njegovateljice u Ljubljani od 1952. do I957. Visina $35 \mathrm{~mm}$. Kolekcija Fischinger.

Due to the health reform of Maria Theresia, the Empress of the AustroHungarian Empire, Doctor Gerhard van Swieten founded a School for Midwives in Ljubljana, as early as $1753 .{ }^{24}$ The school began to present graduation badges to its graduates only after World War II. Two various graduation silver-plated badges are known. The first, rectangular-shaped shows an image of a midwife with a diaper-wrapped new-born baby in her lap in relief and the word around the edges: BABIŠKA ŠOLA LJUBLJANA (School for Midwives, Ljubljana). The badge was awarded until the early ig6os (Fig. 4 , left). The newly designed round badge on the relief features a portrait of

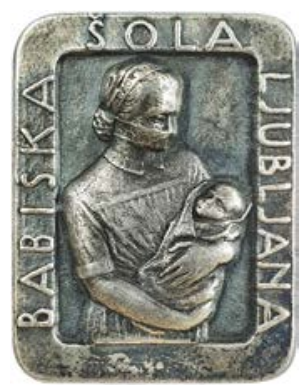

Figure 4, left: Ljubljana's graduation badge of the School of Midwifery, awarded in the I95 os and I96os. Height $28 \mathrm{~mm}$, width $22 \mathrm{~mm}$. Collection Fischinger.

Slika 4., lijevo: diplomska značka primaljske škole u Ljubljani dodijeljivana 50-tih i 6o-tih godina 20. stojeća. Visina mm $28 \mathrm{~mm}$, širina22 $\mathrm{mm}$. Kolekcija Fischinger.

24 Zupanič Slavec, Z. (2018), Začetki porodništva in izobraževanja babic na Slovenskem, in: Zgodovina zdravstva in medicine na Slovenskem. Razvoj ginekologije in porodništva, Ljubljana: Slovenska Matica, Znanstveno društvo za zgodovino zdravstvene kulture Slovenije, 270. 
Figure 4, right: Ljubljana's graduation badge of transformed and renamed into the school School of Midwifery van Swieten, awarded in the i970s and the early ig8os.

Height $37 \mathrm{~mm}$. Collection Fischinger.

Slika 4, desno: diplomska značka preoblikovane i preimenovane škole u Ljubljanska primaljska škola van Swieten, dodijeljivana 7o-tih godina i početkom 8o-tih godina 20.stoleća. Visina $37 \mathrm{~mm}$. Kolekcija Fischinger.

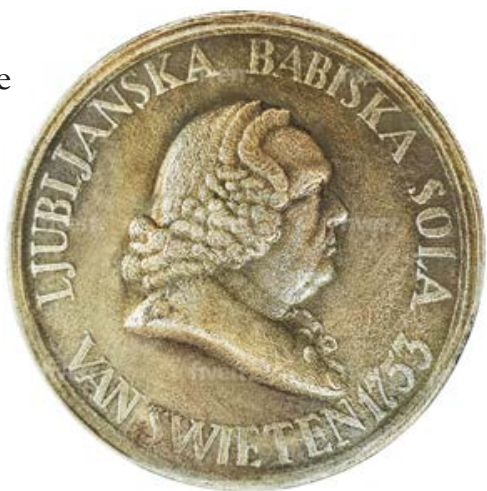

Gerhard van Swieten, the founder of the school. The school title appears along the top edge: LJUBLJANSKA BABIŠKA ŠOLA (Ljubljana's School for Midwives). Along the bottom edge is the inscription: VAN SWIETEN 1753. The badge was awarded from the rg6os to the mid-8os. The academic sculptors who designed these graduation badges are not known. Both badges are marked in the rear with a mark of the maker Josip Štirn, Ljubljana. (Fig.4, right)

After World War II, the School for Nurses was renamed ŠOLA ZA MEDICINSKE SESTRE V SLOVENIJI (School for Medical Nurses, Slovenia). In I954, the School for Medical Nurses in Ljubljana was transformed and renamed into VIŠJA ŠOLA ZA MEDICINSKE SESTRE V LJUBLJANI (Nursing College in Ljubljana). In 1962 the College was transformed and renamed into VŠZD V LJUBLJANI ODDELEK ZA MEDICINSKE SESTRE (College for Health Workers, Department of Nursing Ljubljana). ${ }^{25}$

Figure 2 shows the badge of the School for Medical Nurses, Slovenia (left), the badge of the Nursing College in Ljubljana (centre) and the badge of the College for Health Workers, Department of Nursing Ljubljana (right). Except for titles on the graduating badges faces, the badges are identical in their form and motive to the badges of the School for Nurses at the Institute for Social and Hygienic Protection of Children, which was first issued in 1934. The badges are unmarked on the rear side.

From I950 to I974, nine secondary schools of nursing were established in all major cities in Slovenia (Maribor, I947; Celje, I954; Murska Sobota, I960; Nova Gorica, I96r; Piran, I96r; Jesenice, I962; Ljubljana, I962; Novo Mesto, I963; Slovenj Gradec, I974). At the end of the school year, all medical nursing

25 Gradišek, A. (1974), 145-155. 
schools awarded graduation certificates and graduation badges to their graduates. These badges are the same shape and design as the graduation nurse badges first awarded in 1934. The only difference is in inscribed titles of the schools. The school in Piran did not have the name of the city. The words on the badge are: ŠOLA ZA MEDICINSKE SESTRE V SLOVENIJI (School for Nurses in Slovenia).

From the beginning headmasters pinned the badges on the uniforms of newly graduated nurses (Fig. 5), later graduates received their graduation certificates and badges wearing civilian clothes.

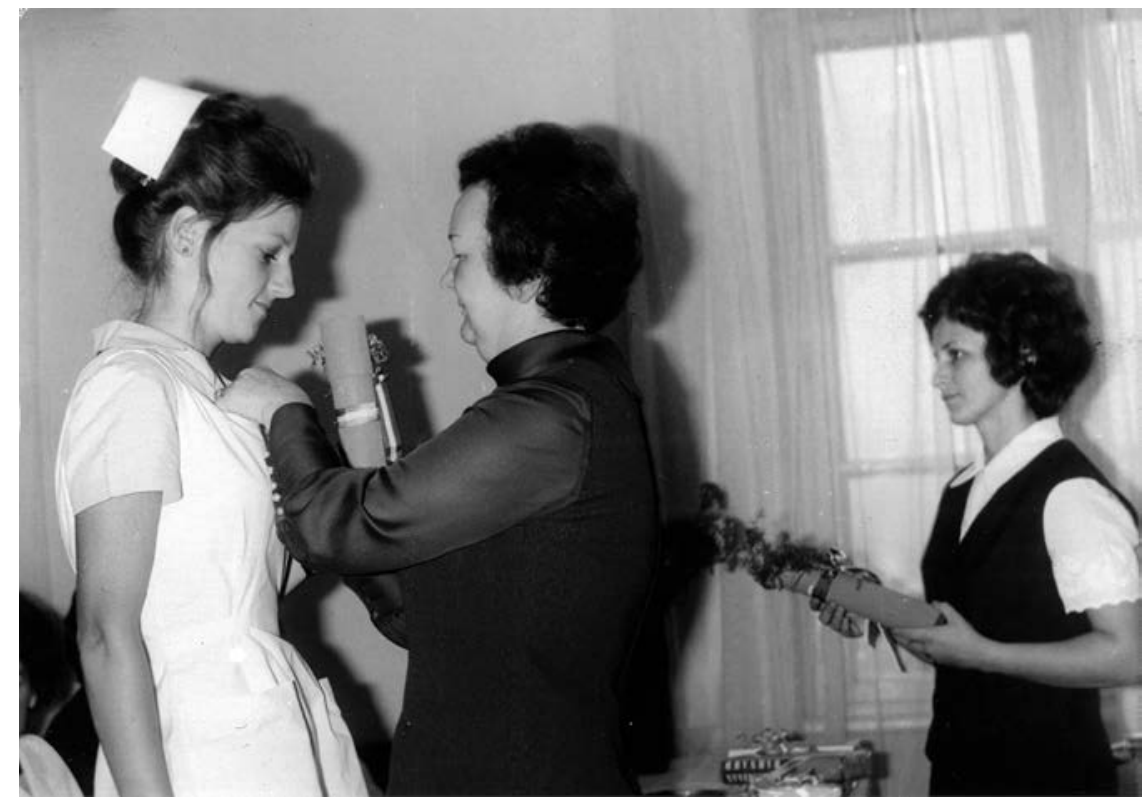

Figure 5. The Headmistress of Jesenice School of Nursing, Miss Mira Jazbinšek, pinning the graduation badge to miss Mojca Thaler's uniform during the 1972 graduation and pinning ceremony.

Photograph courtesy of Miss Mojca Thaler.

Slika 5. Ravnateljica Škole za zdravstvene djelatnike Jesenice Mira Jazbinšek pribada diplomantici - medicinski sestri Mojci Thaler diplomsku značku na uniformu (1972.). Fotografija vlastništvo Mojce Thaler. Ljubaznošću Mojce Thaler.

In the school year $198 \mathrm{I} / 82$, a major reform of secondary education was carried out in Slovenia. Among other modifications, the awarding of graduation badges was ceased in the early r 980 . 
The common findings regarding graduation badges of nurses and midwives awarded in the period from I925 to the early I980s are:

- The awarding of the badges was standard for all Slovenian secondary schools, including Nursing College, Ljubljana.

- From 1935 to the early I980s, all badges had the same design. The badges differed only in the metal from which they were manufactured and in repeated changing of the school names.

- None of the badges were personalised.

- The manner of awarding and wearing badges was not uniform.

- Nothing about the meaning of the badges was explained to the graduates.

- One-fourth of interviewed nurses and midwives could not remember being awarded their badges.

- Nurses graduation badges were worn mainly because of the pride of achieved education.

- The reason for not wearing badges was the fear of losing the badges or a sense of the unimportance of the badges.

- After World War II, the wearing of badges was not mandatory anymore. In the late I970s, the wearing of the badges has almost ceased.

- Many nurses who received their badges in the I970s and early I980s showed no interest in wearing badges at all.

- Less than one-fourth of interviewees still kept their badges. Only a handful of interviewees kept the badge awarded by the Secondary School for Nursing and the Nursing College as well.

- The badges are hardly ever kept in a jewellery box.

- Most nurses keep their badge with documents or somewhere in an apartment or even in the cellar or attic.

In 2017, Full. Prof. Skela Savič, PhD, the Dean of the Angela Boškin Faculty of Health Care (FZAB), Jesenice gave the initiative to restore the tradition of awarding graduation badges to students that have successfully finished their education (Fig.6). A question about the motives for her initiative was sent by e-mail to Prof. Savič. In her reply, the former Dean Skela Savič stated that the FZAB wanted to elevate the recognisability of the study of nursing as well as the recognisability of the nursing profession. Additionally, Prof. Skela Savič thought that graduation badges strengthen self-image and responsibility of the graduates and also present a great commitment to the faculty which awards them. ${ }^{26}$ The badge is designed according to the school's

26 Skela Savič, Brigita, "RE: Prošnja" Message to Duša Fischinger, 25 Nov 2019 [Email]. 


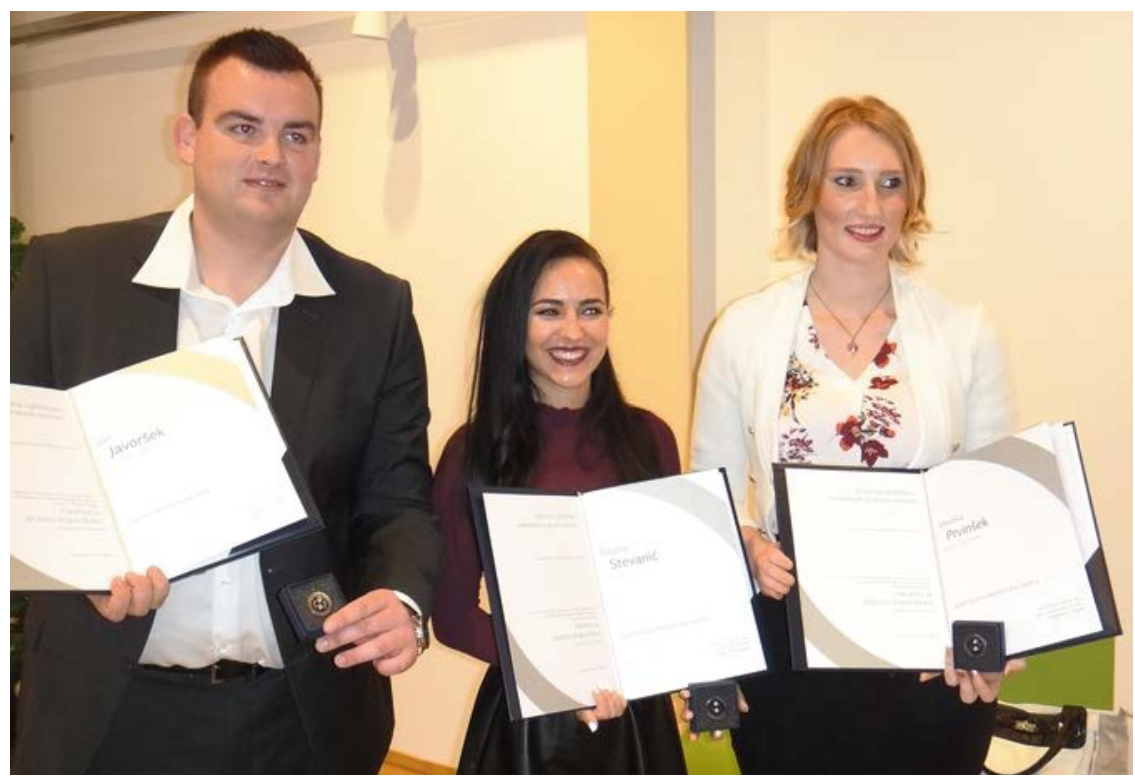

Figure 6. BSN programme graduates of Jesenice Angela Boškin Faculty of Healthcare proudly displaying their diploma certificates and graduation badges (20I7).

Slika 6. Stručni prvostupnici sestrinstva Fakulteta za zdravstvo Angele Boškin, Jesenice ponosno pokazuju diplome i diplomske značke (20I7.).

logo by MA marketing, Vrhnika, and it is manufactured by the engravers Lavrih in Šentvid at Stična and Tomšič, Vrhnika. On the round, partially enamelled badge there is the school's logo, the name of the faculty is inscribed on the edge in Slovene and English. The logo presents the outline of two persons, whose heads are marked with Swarovski crystals, and it can be interpreted in several ways, one of them being the relationship between a student - a future nurse and a patient (Fig.7). The badge uses magnets to attach easily to all clothing.

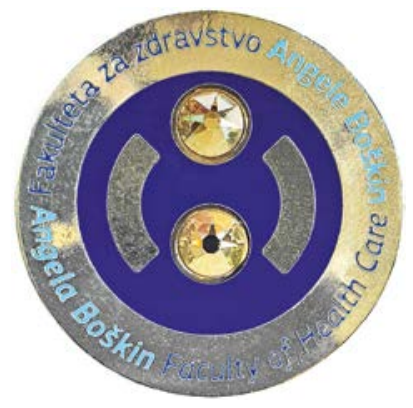

Figure 7. The BSN programme graduation badge of the Angela Boškin Faculty of Health Care Jesenice, awarded for the first time in 2017. Hight $30 \mathrm{~mm}$. Collection Fischinger.

Slika 7. Diplomska značka BSN programa Fakultete za zdravstvo Angele Boškin, Jesenice, prvi put dodijeljena 2017. godine. Visina $30 \mathrm{~mm}$. Kolekcija Fischinger. 


\section{Discusion}

Some nursing schools stopped awarding badges calling them obsolete and unnecessary since identification badges (ID badges) are mandatory in health institutions.

In 1999 Callander - Grant undertook a telephone survey of 30 nationwide nursing colleges in Great Britain and ascertained that the financial considerations were a major contributing factor of many colleges in their decision not to present graduation badges anymore. The additional reasons for ceasing awarding badges could be an amalgamation of many nursing schools in larger nursing colleges, and some of those have not designed badges. ${ }^{27}$ The Dean of University of Applied Health Sciences, Zagreb, Prof. Racz, PhD informed us that in 2013 his predecessor ceased awarding badges with the purpose of redistribution of financial resources to the students needy of financial support. ${ }^{28}$

No reason for cessation of awarding badges in Slovenia can be found in written sources. We presume that financial motives were among the main reasons to cease awarding badges in Slovenia too.

We propose that there are some additional reasons besides the causes for refusing to wear the badges gathered by our interviewing. The badges were not personalised by engraving nurses' names or their initials and the graduation dates.

In addition, in most countries around the world, nursing graduates hear an explanation about the meaning and symbolism of awarding badges which are then awarded to graduates ceremoniously by nursing school leadership or in some cases by the graduate's family members. Many colleges and universities awarded the badge/pin at a separate graduation ceremony (pinning ceremony). ${ }^{29}$ In Slovenia, the badges were simply pinned on the uniform or civil clothes or handed out. For these reasons, many nurses were not emotionally attached to their badges that in addition were not manufactured of precious metals, and that is why so few nurses have kept their badges. Some of the newly educated nurses did not attend the graduation ceremonies and received their diploma certificates by mail. The findings of our research

\footnotetext{
Callander-Grant, S. (2001), 71-74.

Racz, Aleksandar, "RE: dodjeljivanje značaka" Message to Janez Fischinger, 1 Aug 2015 [Email].

29 Anon. The History of the Pinning Ceremony: A Nursing School Tradition. https://www. waldenu.edu/ (accessed: 19 December 2019)
} 
confirmed our hypothesis that some Slovene nurses, as opposed to their foreign counterparts, are not aware of the meaning and importance of awarded badges, they do not prize them enough and are not interested in what happens to their badges. As wearing of the badges was not mandatory, and some nurses had never worn the badges, the majority of nurses abandoned wearing badges.

In some medical facilities, all employees wear identically coloured scrubs and identical ID badges. Nurses not wearing graduation badges cannot be identified by patients as nurses. From a distance, neither an ID badge nor a graduation nurse badge is clearly readable. However, since graduation nurse badges are issued only for nurses, only nurses are allowed to wear them. Unlike the ID badge, only a distinct graduation badge provides the information about where a nurse graduated. Wearing a badge from a top-ranked college or faculty would promote this educational institution and increase the patient's confidence.

Many nursing schools around the world have decided to cease presenting badges to newly graduated nurses. Some health facilities now advise staff not to wear badges for a variety of health and safety reasons, such as infection prevention. ${ }^{30}$ Despite all this, many schools in English-speaking countries still award badges. There are some reasons for the reintroduction of awarding badges. ${ }^{31,32}$ The majority of newly established nursing schools, particularly in the United States of America, have decided to design and award their badges.

Unlike Slovenia, there is a great interest in nursing badges in Western Europe and North America among nurses as well as the public at large. Graduation badges are highly appreciated amongst nurses. Collecting and trading nursing badges is popular. Some Nursing Associations organise 'bring a badge' day meetings to enable nurses to display their badges. ${ }^{33}$ Nurses who have lost their badges, and even relatives of already deceased

30 Shepard, E. (2011), 'Do nurse badges have any relevance to nurses today?' Nursing Times. https://www.nursingtimes.net/roles/nurse-educators/do-nurse-badges-have-any-relevance-to-nurses-today-22-08-2011/ (accessed: 19 December 2019)

31 Grypma, S. (2011), Reintroducing the pinning ceremony, Journal of Christian Nursing, 28(3), 127. https://doi.org/10.1097/CNJ.0b013e31821eb57

32 Snow, T. (2012), Trust brings back badges in bid to celebrate nursing excellence, Nursing Standard, 26 (27), 8. https://doi.org/10.7748/ns2012.03.26.27.8.p7756 (accessed 13 December 2019).

33 Anon. (2011), Bring a Badge Day - 10th February, Royal Infirmary of Edinburgh. Lothian Health Services Archive. (accessed: 5 January 2020) 
nurses, may try to replace the lost badge by purchasing it somewhere, e.g. on eBay.

It seems that at least someone in Slovenia became aware of the importance of graduation badges. In 2013 graduates from the Angela Boškin Faculty of Health Care, Jesenice received an explanation about the history and significance of the badges prior to receiving their BSN badges. Unfortunately, the next award ceremony occurred without any explanation of the meaning of the badges and the graduates were not invited to wear the badges. It would be appropriate to accentuate the meaning of wearing badges prior to awarding them to graduates. Everyone should know what their badge means. In many countries, some nurses proudly wear their graduation badges pinned on their uniforms or ID badges. ID badges do not appear to be a major reservoir for pathogenic organisms. ${ }^{34}$ Why should graduation badges represent a greater hazard if they are regularly cleaned.

Graduation nurse badges can be popularised by organising badge exhibitions, writing about this topic, and encouraging people to wear and collect badges. In Slovenia, a comprehensive public collection of nurse badges still does not exist. The author's collection of badges consists so far of all variants of badges and includes more than 30 pieces. We are aware that some undoubtedly existing badges have not yet been discovered. The dates of the badges described in this paper were retrieved only by authors time-consuming face to face interviewing of many nurses and midwives across Slovenia. As the research is very time consuming, more researchers would be needed for further research. The authors of this paper would be grateful for any additional data concerning the badges of graduate nurses.

34 Ota, K., Profiti, R., Smaill, F., Matlow, AG., Smieja, M. (2007), Identification badges: a potential fomite? Can J Infect Control., 22(3), 162, 165-6. 


\section{Conclusion}

We can argue that the former Slovenian nurses and midwives' graduation badges are almost completely forgotten.

Unfortunately, today not only the public but many healthcare professionals, including nurses and midwives, are unaware that the history of nursing is expressed in once awarded badges. The badges provide evidence of the foundation, operation and development of healthcare schools. For this reason, graduation badges are worth to be studied and should be preserved for future generations as an important aspect of the history of the nursing profession. The badges should be not only careful treasured by their recipients but also collected for display in the planned future Slovenian Museum of Nursing History.

Fortunately, after nearly four decades of cessation of awarding the badges, the awarding of the badges has been reintroduced at one of the Slovenian nursing schools.

The badges are important artefacts of Slovenian cultural heritage. Oral history about nursing badges will quickly disappear if no one writes or researches about them. If the collection of graduating badges does not continue, the badges might one day disappear forever.

Translated by / Prijevod na engleski: Aleš Fischinger, MD

All photographs, except Figure 5, by Aleš Fischinger.

Sve fotografije, osim slike 5, Aleš Fischinger. 


\section{REFERENCES}

1. Anon. (2011), Bring a Badge Day - 10th February, Royal Infirmary of Edinburgh. Lothian Health Services Archive. (accessed: 5 January 2020)

2. Anon. Nursing Pins in Lorrain School of Nursing, lorrainschoolofnursing. ca, Nursing-pins, http://lorrainschoolofnursing.ca/nursing-pins (accessed: 26 January 2020)

3. Anon. The History of the Pinning Ceremony: A Nursing School Tradition. https://www.waldenu.edu/ (accessed: 19 December 2019)

4. Beštak, B. (2006). Značka škole za dječje njegovateljice Medicinskog fakulteta u Zagrebu, Obol XLIV (58), 65-67.

5. Brbora, Z. (2015). Službene značke i odore medicinskih sestara, primalja i bolničarki u Hrvatskoj (1914.-1990.), Dubrovnik: Samozaložba, 1-23.

6. Brown, T. (1952), Nursing school pins. American Journal of Nursing, 52(10), 1224. https://doi.org/10.2307/3459842

7. Callander-Grant, S. (2001), Nurses's badges: archaic symbols or icons of nursing? International History of Nursing Journal, 6(2), 71-74.

8. Dugac, Ž., Horvat, K. (2013), Službeno, praktično i elegantno: o uniformama sestara pomoćnica-medicinskih sestara od 1920-ih do 1940-ih godina u Hrvatskoj, Acta medico-historica Adriatica, 11(2), 251-74.

9. Gradišek, A. (1974), 50 let zdravstvenega strokovnega šolstva na Slovenskem, Zdravstveni obzornik, 8(3), 145-155.

10. Grypma, S. (2011), Reintroducing the pinning ceremony, Journal of Christian Nursing, 28(3), 127. https://doi.org/10.1097/CNJ.0b013e31821eb57

11. Jarnovič, N. (1978), Značke medicinskih sester v Sloveniji, Zdravstveni obzornik, 12(1), 54-5.

12. Kaijser, K. (1985). Broscher $i$ svensk sjukvard, Stockholm: Svensk sjuksköterskeföring, 1-60.

13. Keršič, I., Klemenc, D. (2016). Pogovor z gospo Marušo Šolar, dobitnico priznanja Zbornice - Zveze za življenjsko delo Angele Boškin, Utrip XXIV (9), 13-15.

14. Keršič, I., Magajne, N., Sima, D., Leskovec, I. (2011). Medicinske sestre skozi čas, Ljubljana: Društvo medicinskih sester, babic in zdravstvenih tehnikov Ljubljana, 27.

15. Kozon, V. (2006). Pflegephaleristik-Katalog Österreich, Wien: ÖGVP, 8, 11.

16. Meglaughlin, J. (1990). British nursing badges, London: Vade - Mecum Press, 40$41,47$.

17. Meixner Reed, M. (2009), American nursing pins in history and context, [Nurse-enterpreneur-network]. https://sites.google.com/site/nursingpinsandcollectibles (accessed: 26 November 2019) 
18. Ota, K., Profiti, R., Smaill, F., Matlow, AG., Smieja, M. (2007), Identification badges: a potential fomite? Can J Infect Control., 22(3), 162, 165-6.

19. Pirc, I. (1938). Zdravstvene prilike in delo higijenskih ustanov v Sloveniji 1922 1936. Zdravje v Sloveniji, II knjiga. Ljubljana: Higijenski zavod v Ljubljani, 437.

20. Racz, Aleksandar (2015), "RE: dodjeljivanje značaka” Message to Janez Fischinger, 1 Aug 2015 [Email].

21. Shepard, E. (2011), 'Do nurse badges have any relevance to nurses today?' Nursing Times. https://www.nursingtimes.net/roles/nurse-educators/do-nurse-badges-have-any-relevance-to-nurses-today-22-08-2011/ (access: 19. December 2019)

22. Skela Savič, Brigita (2019), "RE: Prošnja” Message to Duša Fischinger, 25 Nov 2019 [Email].

23. Snow, T. (2012), Trust brings back badges in bid to celebrate nursing excellence, Nursing Standard, 26 (27), 8. https://doi.org/10.7748/ns2012.03.26.27.8.p7756 (accessed: 13 December 2019).

24. Šuštar, B. (1992). Šola za sestre: zdravstveno šolstvo na Slovenskem: razstavni katalog, Ljubljana: Slovenski šolski muzej, 123-4.

25. Zupanič Slavec, Z. (2018), Začetki porodništva in izobraževanja babic na Slovenskem, in: Zgodovina zdravstva in medicine na Slovenskem. Razvoj ginekologije in porodništva, Ljubljana: Slovenska Matica, Znanstveno društvo za zgodovino zdravstvene kulture Slovenije, 270. 


\section{SAŽETAK}

Uvod: U mnogim zemljama diljem svijeta diplomanticama sestrinskih $i$ primaljskih škola dodjeljivane su, a i danas se dodjeljuju, diplomske značke. Slovenske zdravstvene škole su i prije i nakon Drugoga svjetskog rata pohađale učenice iz mnogih krajeva nekadašnje Kraljevine, poslije Republike Jugoslavije. Tim je polaznicama škola uz diplomu uručivala $i$ diplomsku značku, koju bi neke diplomantice nosile na svojim odorama radeći u zdravstvenim ustanovama na području nekadašnje Kraljevine, odnosno Republike Jugoslavije. Glavna namjera ovoga povijesnog istraživanja bila je utvrditi koje su slovenske zdravstvene škole dodjeljivale diplomske značke $i$ kako su značke izgledale. Tragali smo za razlozima zbog kojih su škole odustale od dodjeljivanja značaka $i$ što je ponukalo Fakultet za zdravstvo Angele Boškin, Jesenice, da uvede uručivanje diplomske značke. Metode: Zbog gotovo potpunog nedostatka pisanih izvora o diplomskim značkama uspjeli smo "face to face" ili preko telefona intervjuirati 393 većinom umirovljene medicinske sestre i primalje - dobitnice diplomske značke. Njihove smo značke fotodokumentirali. Sakupljanjem iz raznih izvora izgradili smo i privatnu zbirku značaka. Rezultati: Dokazali smo da su u 2o. stoljeću sve slovenske srednje zdravstvene škole $i$ Viša šola za medicinske sestre u Ljubljani dodjeljivale diplomske značke. Opisano je i prikazano pet različitih tipova značaka. Prva diplomska znač$k a$ dodijeljena je prvoj generaciji diplomantica prvoutemeljene sestrinske škole u Sloveniji u Ljubljani I925. U kasnim 70-im i do početka 80-ih godina prošlog stoljeća sve slovenske zdravstvene škole odustale su od dodjeljivanja značaka. Traganje za uzrocima ostalo je bezuspješno. Manje od jedne petine sudionica intervjua još uvijek čuva svoju značku. Opisana je $i$ prikazana $i$ diplomska značka, koju od 2017. dodjeljuje Fakultet za zdravstvo Angele Boškin. Rasprava i zaključak: Mnoge slovenske medicinske sestre i primalje nisu dovoljno svjesne značenja i važnosti svojih diplomskih značaka. Unatoč važnosti značaka za vizualni $i$ profesionalni identitet medicinske sestre, danas su značke kao simbol sestrinstva gotovo potpuno zaboravljene. Međutim, ove su značke male umjetnine i dokaz su postojanja i razvoja slovenskih zdravstvenih škola. Dio su povijesti slovenskog sestrinstva i slovenske kulturne baštine. Značke zaslužuju da se o njima govori i piše i trebale bi biti izložene u planiranom Muzeju zdravstvene njege.

Ključne riječi: diplomske značke, povijest sestrinstva i primaljstva, sestrinske i primaljske škole, Slovenija, 20. stoljeće 